УДК 37.01-047.22(477)

DOI 10.35423/2078-8142.2020.2.2.14

$$
\begin{array}{r}
\text { О. І. Якимчук, } \\
\text { кандидат філософських наук, }
\end{array}
$$
дочент кафедри психосоматики та психологічної реабілітації Національного педагогічного університету імені М. П. Драгоманова м. Київ, Україна e-mail: yakymchuk-o@ukr.net ORCID: https://orcid.org/0000-0003-2358-5622

\title{
КОМПЕТЕНТНІСНИЙ ПІДХІД В ОСВІТІ: УКРАЇНСЬКІ РЕАЛІЇ
}

Одним з найважливіших напрямів реформування сучасної украӥнської освіти є всебічне наскрізне впровадження та застосування компетентнісного підходу в навчанні, вихованні, практичній підготовиі школярів. Традиційна знаннєво-інформаційна парадигма навчання виявилася неконкурентоспроможною: учні могли мати обширні знання, однак не могли їх реалізувати на практиці. Як засвідчують дослідження, «стара» школа була переобтяжена формальними знаннями, які відсторонювали дитину від реальності. Практика доводить, щуо освітяни мають шукати нові, інноваційні, особистісно- і практично-орієнтовані методології навчання $i$ виховання. Переорієнтація освіти на компетентнісну парадигму потребує додаткових досліджень. Дану статтю присвячено визначенню сутності компетентнісного підходу та можливості втілення теоретичних знань про нього в освітній практиці Украйни.

Ключові слова: людина, освіта, компетентність, знання, вміння, навички, цінності, практична орієнтація освіти, життєтворчість освіти.

Однією із суттєвих вад «старої» школи є перенавантаження школярів формальними, теоретичними знаннями, якими вони не вміли (й не мали змоги) користуватись як у процесі навчання, так i 
в повсякденному житті. Знання перетворювались на баласт, на їх засвоєння безрезультатно витрачалась значний обсяг часу й енергії. Замість підготовки особистості до життя формальна шкільна освіта відсторонювала людину від суспільства, його реальних проблем та суперечностей розвитку. Дитина втрачала сенс життя й часто-густо обирала асоціальні форми мислення та дії. У такому вимірі, школа для учня ставала дедалі більш не цікавою, а може й непотрібною. Повернення школі її суспільного призначення та статусу потребувало змін, які «вирівняли» б знання, оптимально збалансували їх теоретичний і соціально-практичний зміст, а головне - сформували в учнів здатність користуватись цими знаннями у своїй практичній діяльності. Виконання цього завдання здійснено шляхом перебудови школи на основі компетентнісного підходу.

Головним завданням освіти $є$ підготовка людини до повноцінної життєдіяльності в актуальному соціально-цивілізаційному та соціокультурному середовищі, а також вироблення особистісних можливостей адаптації до змінних соціальних, технологічних, професійних, інформаційних умов. Враховуючи високу динаміку сучасних суспільних змін у всіх сферах соціального функціонування, людина також має сформувати доволі гнучку, високоадаптативну, інноваційно орієнтовану особистісно-компетентнісну сферу з високим рівнем світоглядно-культурної свободи. «Суспільству XXI століття, що активно розвивається, потрібні люди, які мають сучасну освіту, моральнісні переконання, підприємницьку енергію, які можуть самостійно приймати відповідальні рішення в ситуації вибору, прогнозуючи їх можливі наслідки, які здатні до співробітництва і вирізняються мобільністю, динамізмом, конструктивністю, володіють розвинутим почуттям відповідальності за долю країни. Такі властивості може мати лише компетентна та впевнена у своїх силах людина» [1, с. 9]. Формування таких властивостей значною мірою відбувається в освітній сфері. I хоча набуття особистісних компетенцій багато в чому залежить від докладання людиною індивідуальних зусиль, навчальні заклади, зокрема загальноосвітні, мають створювати умови, в яких такі зусилля даватимуть найпозитивніший результат. 
Саме результативність шкільної освіти виходить на перший план, коли йдеться про впровадження компетентнісного підходу. При цьому результатом тут вважається не вміння успішно скласти теоретичні екзамени, як це було в радянській освіті, а набуття корисних для реального життя та соціальної адаптації компетентностей, які і надалі мають потенціал розширення і вдосконалення, що єднає процесуальний та результативний аспект навчання в певну системну цілісність. «У шкільній освіті перехід до компетентнісного підходу, за одностайною думкою науковців і практиків, означає переорієнтацію з процесу на результат освіти в діяльнісному виміpi, розгляд цього результату з погляду затребуваності в суспільстві, забезпечення спроможності випускника школи відповідати новим запитам ринку, мати відповідний потенціал для практичного розв'язання життєвих проблем, пошуку свого «Я» в професії, в соціальній структурі. Виявилось, що для презентації змісту освіти, який відповідав би таким вимогам, узвичаєних у вітчизняній педагогіці понять не достатньо» [2, с. 45-46]. Раніше освіта традиційно орієнтувалася на такі категорії результативності, як знання, вміння та навички. Сьогодні вони втрачають актуальність через іманентну завершеність, кінцевість, результативну обмеженість. Тому конче потрібним є введення філософсько-освітньої категорії «компетентність», в яку закладається не лише набуття конкретних здібностей, а й глибинно-особистісне прищеплення кожному учню чи студенту ціннісного ставлення до свого подальшого освітнього саморозвитку. Сучасна освіта має надавати людині цілісну єдність знань, компетенцій і цінностей, орієнтовану як на успішну самореалізацію в сьогоднішніх суспільних умовах, так і на успішну адаптацію до їх подальших змін. Це й зумовлює високу актуальність дослідження компетентнісного підходу в системі навчання та виховання особистості.

Проблема компетентнісного підходу в освіті належить до активно досліджуваних. Найбільш вагомий внесок в іiі розроблення зробили такі вітчизняні науковці, як Т. Андрющенко, Н. Бібік, I. Срмаков, О. Пометун, Д. Пузіков, О. Овчарук, Г. Михайлишин, С. Якушева та ін. Названі питання неодноразово ставали предметом досліджень цих та інших науковців, однак доводиться констатувати, що малодослідженими залишаються окремі способи ком- 
петентнісного підходу у вітчизняній освіті. Серед зарубіжних дослідників аналізованої проблеми слід виокремити Дж. Равена, Д. Лотнера, С. Флейшера, Ю. Грюнкорна, Е. Кліма, П. Давидова та ін.

Метою та завданням нашої статті є обгрунтування сутності компетентнісного підходу та можливості втілення теоретичних знань про нього в освітній практиці України.

Отже, звернемося до детального концептуальнотеоретичного аналізу базових сутнісних ознак компетентнісного підходу в освіті. Ця проблематика сьогодні актуальна ще й тому, що в Україні тільки розпочинається реальна активізація процесу переходу до компетентнісних методик навчання і виховання в системі середньої освіти. Це зумовлює потребу всебічного аналізу як зарубіжного досвіду, так і тих можливостей, що надають вітчизняні освітні традиції щодо переходу до застосування в системі навчання і виховання особистості компетентнісних принципів та орієнтирів. «Компетентнісний підхід є одним із стратегічних напрямів розвитку системи освіти України, їі новим концептуальним орієнтиром. I хоча на сучасному етапі розвитку наукового знання немає єдиного підходу щодо трактування понять «компетентнісний підхід» і «компетентність», на думку вчених (Н. Бібік, О. Пометун, О. Овчарук та ін.), важливим є розуміння того, що компетентнісно орієнтована освіта передбачає перенесення акценту із засвоєння дітьми нормативно визначених знань, умінь і навичок на формування і розвиток у них здатності самостійно діяти, адекватно застосовуючи знання та індивідуальний досвід у нестандартних життєвих ситуаціях, отримання практичних результатів, вироблення власних ставлень у тих, хто навчається» [3, с. 8-9]. Така освіта даватиме можливість не лише досягати етапних учбових чи професійних успіхів, а й на особистісно-ціннісному рівні визначати для себе важливі життєтворчі цілі та досягати їх, застосовуючи навчально-компетентнісний базис та індивідуальні можливості навчатися безперервно впродовж всього життя. Саме тому ми говоримо не просто про навчання і виховання, а про набуття особистісносистемної цілісності знань, компетенцій і цінностей, орієнтованих на всебічні прояви життєвого успіху конкретної людини. 
При цьому компетентнісний підхід в освіті не заперечує важливість набуття традиційних знань, вмінь та навичок, котрі також можуть корисно застосовуватися людиною у професії чи буденному житті. Однак новий підхід наголошує на тому, що ці феномени не є самоціллю, кінцевим освітнім результатом. Вони мають продовжуватися, транслюючись в активну життедіяльність особистості, сповнюючись аксіологічними та життєвотелеологічними компонентами. «Знання, вміння та навички, котрі молодь набуває й виробляє, навчаючись у школі, беззаперечно, $є$ важливими. Поряд із цим сьогодні актуальності набуває поняття компетентності учня, що визначається багатьма чинниками, оскільки саме компетентності, на думку багатьох міжнародних експертів, є тими індикаторами, що дозволяють визначити готовність учня-випускника до життя, його подальшого особистого розвитку й до активної участі в житті суспільства. Орієнтуючись на сучасний ринок праці, освіта до пріоритетів сьогодення відносить уміння оперувати такими технологіями та знаннями, що задовольнять потреби інформаційного суспільства, підготують молодь до нових ролей у цьому суспільстві. Саме тому важливим нині $є$ не тільки вміння оперувати власними знаннями, а й бути готовим змінюватись та пристосовуватись до нових потреб ринку праці, оперувати й управляти інформацією, активно діяти, швидко приймати рішення, навчатись упродовж життя. Прогресивна освітня спільнота сьогодні ставить перед собою нове завдання - сформувати в школяра та дорослого вміння вчитись» [4, с. 7]. У цьому й полягає базова сутність компетентнісного підходу в освіті, що й робить його принципи надзвичайно актуальними для сучасної людини, особливо молодої. Сьогодні немає сенсу фіксувати в індивідуальній свідомості, когнітивній та аксіологічній сфері сталі інформаційнознаннєві комплекси чи технологічні вміння, адже будь-яка технологія швидко застаріває, змінюючись новітніми знахідками. Інформація також курсує та змінюється 3 надзвичайною динамікою. У такому світі неможливо бути успішним на сталих знаннєвих засадах. Особистість має бути динамічною, активною, інноваційноналаштованою, компетентнісно орієнтованою системою.

В українському філософсько-освітньому та теоретикопедагогічному дискурсі сьогодні лише відбувається концептуальне 
та категоріальне становлення парадигми компетентнісного підходу в освіті. Водночас, можемо стверджувати, що вітчизняні освітяни вже мають значні здобутки у цій галузі. Так, компетентнісний підхід вже закладений в основу прийнятого у 2017 р. закону «Про освіту». Цей закон важливий як $з$ практичної, так і $з$ теоретичноконстатуючої точки зору. Так, у ньому визначаються базові категорії, якими тепер можуть оперувати українські педагоги та управлінці у сфері освіти. У контексті нашого дослідження сутності компетентнісного підходу в освіті важливим $\epsilon$ те, що у ст. 1 «Основні терміни та їх визначення» закону «Про освіту» дається визначення: «... компетентність - динамічна комбінація знань, умінь, навичок, способів мислення, поглядів, цінностей, інших особистих якостей, що визначає здатність особи успішно соціалізуватися, провадити професійну та/або подальшу навчальну діяльність» [5]. Отже, тут чітко і структуровано дане визначення категорії «компетентність», на яке тепер можна орієнтуватися, досліджуючи компетентнісний підхід як процес формування особистісно-системної єдності знань, компетенцій та цінностей людини, що навчається.

На нашу думку, однією з найважливіших сутнісних ознак компетентнісного підходу в освіті $\epsilon$ те, що навчально-виховний процес набуває максимально потужного соціалізаційного потенціалу. Це виявляється в тому, що освіта не лише дає людині знання і вміння, що вже вироблені в суспільстві і застосовуються, а й формує в особистості здатність адаптації до нових способів соціального і технологічного функціонування. Людина тут перетворюється на єдність особистісно-творчого і суспільно-прогресивного. У сучасному навчально-виховному процесі «ключові компетентності пов'язують воєдино особистісне й соціальне в освіті, відбивають комплексне оволодіння сукупністю способів діяльностей, що створює передумови для розроблення індикаторів їх вимірювання; вони виявляються не взагалі, а в конкретній справі чи ситуації; їх набуває молода людина не лише під час вивчення предметів, групи предметів, але й засобами неформальної освіти, внаслідок впливу середовища тощо. Зарубіжні й вітчизняні автори наголошують, що ключові компетентності змінні, мають рухливу і перемінну структуру, залежать від пріоритетів суспільства, цілей освіти, особливо- 
стей і можливостей самовизначення особистості в соціумі» [2, с. 46]. Це й визначає ключові сутнісні параметри компетентнісного підходу в освіті. Його застосування в педагогічній практиці вітчизняної школи означає перехід до таких освітніх принципів, які найбільшою мірою відповідали б актуальним потребам соціуму та стратегічним орієнтирам особистісного розвитку кожної людини, що навчається.

Компетентнісний підхід, крім того, дає можливість молодій людині краще зорієнтуватися у виборі власної життєвої стратегії. Ті форми освіти, що домінували в радянські і пострадянські часи, мало допомагали дитині й молодій людині у виборі майбутньої професії. Фактично випускник школи опинявся один на один із соціальною реальністю і найчастіше діяв за обставинами чи сімейними «можливостями». Сучасна ж освіта в іiі компетентнісному вимірі готує молоду людину до свідомого, особистісно орієнтованого професійного вибору. «Парадигма компетентності віддзеркалює вміння розв'язувати реальні проблеми, бути фахівцем у конкретній сфері діяльності, забезпечувати необхідний результат. Основним завданням сучасної освіти повинна стати підготовка не лише знаючих, а й мислячих фахівців, спроможних до подальшого саморозвитку і самовдосконалення» [6, с. 428]. Сучасні тенденції ринку праці чітко засвідчують, що затребуваними є ті фахівці, які в свою діяльність здатні привносити інноваційно-творчий елемент. Формування ж інноваційно-творчого, гнучкого, варіативного мислення $є$ однією із сутнісних ознак компетентнісного підходу в освіті. «Вміння самостійно вчитися, шукати, систематизувати, аналізувати інформацію і ефективно розпоряджатися своїм часом є безальтернативними атрибутами сучасного успішного спеціаліста» [9, с. 52]. Через це традиційна знаннєва парадигма освіти вже не відповідає актуальному суспільному запиту щодо професійних характеристик фахівців у різних сферах. Як засвідчує практика розвинених країн, тільки компетентнісний підхід до змістовного сповнення та формально-організаційного забезпечення навчальновиховного процесу в загальноосвітній школі може гарантувати повноцінну підготовку молоді до активного включення у соціальне життя. 
Сутність компетентнісного підходу в освіті полягає в орієнтації і концентрованій увазі на нову якість навчально-виховної результативності. Результатом навчання і виховання тепер вважається не сума знань, а здатність на особистісному рівні реалізовувати знання і навички в реальних життєвих ситуаціях. Особистісний рівень означає ціннісне ставлення людини до отриманих знань чи навичок, диференційований до них підхід, самостійний аналіз їх ефективності при використанні в буденних чи професійних практичних обставинах. «Мету і результат навчання коректно відрекомендовувати саме як компетентність. В контексті навчання компетентність є вміння справлятися із завданнями і проблемами; це деякий комплекс, котрий пов'язує компетентність воєдино знання, вміння і дії, тобто спроможність мобілізувати вміння в конкретній ситуації. Узагальненим віддзеркаленням спроможності людини діяти ефективно за межами стандартних ситуацій є компетентнісний підхід. Компетентнісний підхід концептуально протистоїть підходу знаннєвому - трансляції готового знання. Він здійснює спробу додати особистісний смисл в процес оволодіння знаннями, акцентуючи увагу на результаті освіти - причому, в якості результату розглядається не сума засвоєної інформації, а здатність людини ефективно діяти в різноманітних проблемних ситуаціях» [6, с. 429]. Для того, щоб реально готувати молодь до такої ефективної діяльності в найрізноманітніших життєвих і професійних обставинах, конче потрібним є кардинальне реформування освіти в усіх ii вимірах. Перехід до парадигми компетентнісного підходу відбувається досить складно, адже узвичаєні освітні стереотипи, попри всю очевидність їх неефективності і згубності, долаються важко. Українська школа має сповнюватися педагогічними кадрами нового покоління, які будуть не лише 3 навчально-технологічної, а й зі світоглядно-ціннісної точки зору підготовленими до повноцінного застосування компетентнісного підходу та інноваційно-гуманістичних методик навчання і виховання.

Однією з базових, світоглядно-фундаментальних проблем традиційної знаннєво-орієнтованої освіти була і залишається значна відірваність знань, що набуваються учнями, від конкретних реалій життя у сучасному суспільстві і сучасній цивілізаційно- 
технологічній реальності. Зі світоглядно-ціннісної точки зору сутність компетентнісного підходу в освіті полягає саме в тому, щоб зробити навчально-виховний процес орієнтованим на підготовку до реальної життєдіяльності, життєтворчості та розбудови особистісної життєвої стратегії. Шкільна освіта має формувати у молодої людини насамперед життєтворчу компетентність, яку можна визначити як «системну властивість особистості: цілісну, ієрархічну динамічну систему здатностей (або окремих компетенцій), яка дозволяє ій свідомо і творчо визначати і здійснювати власне життя, розвивати свою індивідуальність, досягти успішної, оптимальної життєдіяльності в умовах середовища (технологічного, економічного, політичного, соціального, культурного), яке перманентно змінюється» [4, с. 19]. У сучасному світі справді кардинально змінилися правила соціалізації. Якщо раніше певного освітнього рівня могло вистачити людині на все життя, то сьогоднішні реалії вимагають постійного освітнього самовдосконалення. Компетентнісний підхід в освіті поєднує ефективність практичної підготовки з виробленням вміння вчитися продовж усього життя та адаптативно сприймати будь-які соціально-технологічні зміни. Це є одним 3 найважливіших моментів, які визначають загальну сутність компетентнісного підходу в освіті.

Якщо філософсько-освітня парадигма компетентнісного підходу сприймається вітчизняними освітянами доволі консенсусно, то іiі практично-реалізаційний вимір викликає значні суперечки і навіть певний педагогічний спротив. Що ж являє собою процес навчання і виховання, заснований на принципах компетентнісного підходу? 3 операційної точки зору компетентнісний підхід в освіті застосовується на основі такої загальної схеми: 1) конструювання теоретичної компетентнісної моделі для тієї чи іншої предметної сфери чи конкретної ситуації «функціонального мислення»; 2) адаптація розробленої компетентнісної моделі тестування до психометричних, вікових, освітньо-спеціалізаційних особливостей учнів чи студентів; 3) розробка процедури вимірювання компетентнісних характеристик тих, хто навчається (тут можуть застосовуватися найрізноманітніші види контрольних робіт і тестувань); 4) вимірювання ефективності застосованої моделі оцінки компетентності, тих, хто навчається, та визначення напрямів ії вдоскона- 
лення [8, с. 391]. Таким чином, компетентнісний підхід передбачає не лише навчання, виховання і розвиток учнів і студентів, а й постійне вдосконалення самого навчально-виховного процесу, а також безперервне самовдосконалення суб'єктів, які його здійснюють вчителів, педагогів-вихователів, організаторів освітнього простору тощо.

Таким чином, підводячи підсумки нашого концептуальнотеоретичного аналізу фундаментальних сутнісних характеристик компетентнісного підходу в освіті, підкреслимо, що ключовою його ознакою $є$ перехід від накопичення знаннєво-інформаційних масивів та надмірної теоретизації до підсилення практичної, застосувальної, життєтворчої результативності навчально-виховного процесу. «Компетентнісний підхід акцентує увагу на результатах освіти, причому, як результат розглядається не сума засвоєної інформації, а спроможність людини діяти у різних проблемних ситуаціях. Набір цих ситуацій залежить від типу освітньої установи. Загальні вимоги до освіченості спеціалістів можна віднести до ключових компетенцій, наприклад, мати широкий світогляд, бути спроможним осмислювати різні життєві явища, самостійно відшукувати істину: бути здібними проектувати (прогнозувати) свою діяльність; бути самостійними в діях за умов невизначеності» [9, с. 127]. Як бачимо, компетентнісний підхід не означає простої, безпосередньої, механічної підготовки індивіда до здійснення якихось професійно чи життєво корисних дій. Нi, він скоріше орієнтований на вироблення в особистісній структурі людини такої єдності знань, компетенцій та цінностей, яка даватиме можливість протягом життя самостійно оцінювати власні орієнтири і компетентності, а також активно застосовувати знання і вміння 3 метою приносити користь собі і суспільству.

Таким чином, розглянувши філософсько-освітні сутнісні характеристики компетентнісного підходу в освіті, підкреслимо, що на відміну від традиційної інформаційно-знаннєвої парадигми, базовим завданням якої є закріплення у свідомості людини, що навчається, заданих теоретичних установок, компетентнісний підхід орієнтований на підготовку людини до особистісно практичної самореалізації в різних життєвих середовищах (сімейно-побутовому, 
професійно-спеціалізованому, цивілізаційно-технологічному, культурно-творчому, соціально-громадському, соціальноекономічному, суспільно-політичному тощо). За визначенням українських експертів, що брали участь у розробці вітчизняного Закону «Про освіту», компетентність - це динамічна комбінація знань, умінь, навичок, способів мислення, поглядів, цінностей, інших особистих властивостей, що визначає здатність особи успішно соціалізуватися, провадити професійну та/або подальшу навчальну діяльність. Відзначимо важливість саме динамічної, змінної, саморозвиваючої структури будь-якої особистісної компетентності. Саме тому застосування компетентнісного підходу у вітчизняній школі сприятиме реальній підготовці учнівської молоді до тих життєвих, професійних, громадських ситуацій, які можуть їх очікувати в сучасному світі, який надзвичайно швидко змінюється $\mathrm{i}$ розвивається, особливо в технологічній сфері.

\section{ЛITЕРАТУРА}

1. Компетентностный подход в образовании: методологический аспект / ред. С. Д. Якушевой. Новосибирск : Издательство СибАК, 2016. $248 \mathrm{c}$.

2. Бібік Н. М. Компетентнісний підхід: рефлексивний аналіз застосування. Компетентнісний підхід у сучасній освіті: світовий досвід та українські перспективи: Бібліотека з освітньої політики / заг. ред. О. В. Овчарук. Київ : К.І.С., 2004. С. 45-50.

3. Андрющенко Т. К. Компетентнісний підхід як стратегічний напрям розвитку освіти в Україні: теоретичний аспект. Педагогічна освіта: теорія і практика. Збірник наукових пращь. Кам'янець-Подільський : Видавець ПП Зволейко Д. Г., 2013. Вип. 13. С. 8-12.

4. Єрмаков І. Г. Проектне бачення компетентнісно спрямованої 12-річної школи: Практико-зорієнтований посібник / I. Г. Срмаков, Д. О. Пузіков. Запоріжжя : Центріон, 2005. 112 с.

5. Закон України «Про освіту» від 05.09.2017 № 2145-VIII. Вidoмості Верховної Ради. 2017. № 38-39.

6. Михайлишин Г. Й. Діагностика компетентнісного підходу в сучасній освіті. Гілея: науковий вісник. Збірник наукових праць. Київ : ВIP УАН, 2012. Вип. 65 (№ 10). С. 428-435. 
7. Равен Дж. Педагогическое тестирование: Проблемы, заблуждения, перспективы. Москва : Когито-Центр, 2001. 142 с.

8. Competence Assessment in Education: Research, Models and Instruments / eds. Detlev Leutner, Jens Fleischer, Juliane Grünkorn, Eckhard Klieme. Cham : Springer, 2017. 503 p.

9. Давидов П. Компетентнісний підхід в освіті: онтологічногносеологічний аналіз. Науковий вісник Чернівецького університету: Збірник наукових праџь. Філософія. Чернівці: Чернівецький національний університет, 2011. Вип. 541-542. С. 126-130.

\section{REFERENCES}

Yakusheva, S. (Ed.) (2016). Competence approach in education: methodological aspect: Monograph. Novosibirsk. 248 p. [In Russian].

Bibik, N. (2004). Competence approach: reflexive analysis of application. Competence approach in modern education: world experience and Ukrainian perspectives: Library of educational policy. Ovcharuk O (ed.). pp. 45-50. [In Ukrainian].

Andryushchenko, T. (2013). Competence approach as a strategic direction of education in Ukraine: theoretical aspect. Pedagogical education: theory and practice. Collection of scientific works. Kamyanets-Podilsky: Issue 13, pp. 812. [In Ukrainian].

Yermakov, I., Puzikov, D. (2005). Project vision of a competency-oriented 12year school: Practical-oriented tutorial. Zaporizhzhia: Centrion. 112 p. [In Ukrainian].

The Law of Ukraine «On education» from 05.09.2017 number 2145-VIII. Information of the Verkhovna Rada. Vol. 38-39. [In Ukrainian].

Mykhailyshyn, H (2012). Diagnosis competence approach in modern education. Hileya: naukovyy visnyk. Zbirnyk naukovykh prats' (Gileya: scientific bulletin. Collection of scientific works), Issue 65. pp. 428-435. [In Ukrainian].

Raven, J. (2001). Pedagogical testing: Problems, misconceptions, prospects.142 p. [In Russian].

Detlev Leutner, Jens Fleischer, Juliane Grünkorn, Eckhard Klieme (Ed.) (2017) Competence Assessment in Education: Research, Models and Instruments. Cham. 503 p. 
Davydov, P. (2011). Competence approach in education: ontological, epistemological analysis. Scientific Bulletin of Chernivtsi University: Collection of scientific papers. Philosophy. Chernivtsi: Chernivtsi National University. Issue 541-542, pp. 126-130. [In Ukrainian].

\title{
Oksana Yakymchuk
}

Candidate of Philosophical Sciences (Ph.D.), Associate Professor of Psychosomatics and Psychological Rehabilitation, National Pedagogical Dragomanov University; Kyiv, Ukraine; e-mail: yakymchuk-o@ukr.net; ORCID: https://orcid.org/0000-0003-2358-5622

\section{Competence approach in education: Ukrainian realities}

\begin{abstract}
s
One of the most important areas of reforming modern Ukrainian education is the comprehensive, all-encompassing implementation and application of the competency approach in teaching, education, practical training of students. The traditional knowledge-information paradigm of learning proved to be uncompetitive: students could have extensive knowledge, but could not put it into practice. Studies show that the old school was overloaded with formal knowledge that removed the child from reality. Practice has shown that educators should look for new, innovative, personality- and practice-oriented methodologies of teaching and education. The reorientation of education to the competence paradigm requires additional research. This article is devoted to clarifying the essence of the competence approach and the possibility of implementing theoretical knowledge about it in the educational practice of Ukraine. Having studied the philosophical and educational essential characteristics of the competence approach in education, we emphasize that in contrast to the traditional information-knowledge paradigm, the basic task of which is to consolidate in the minds of learners, given theoretical attitudes, competence approach focuses on preparing people for personal selfrealization. different living environments (family-domestic, professionalspecialized, civilizational-technological, cultural-creative, socio-social, socioeconomic, socio-political, etc.). The article notes the importance of a dynamic, variable, self-developing structure of any personal competence. That is why the application of the competency approach in the domestic school will contribute to the real preparation of students for those life, professional, social situations
\end{abstract}


that may await them in today's world, which is changing and evolving extremely rapidly, especially in the technological field.

Keywords: human, education, competence, competence approach in education, knowledge-information paradigm of education, knowledge, skills, abilities, values, practical orientation of education, life-giving of education. 